\title{
Aday Öğretmen Yetiştirme Sürecini Değer- lendirmeye Yönelik Ölçek Geliştirme Çalışması
}

DOI: $10.26466 /$ opus.361334

\author{
Hasan Hüseyin $\mathrm{Aksu}^{*}$ - Tuğçe Durmuş** \\ *Doç. Dr, Giresun Üniversitesi, Eğitim Fakültesi, Giresun/Türkiye \\ E-Posta: hhaksu74@gmail.com \\ ORCID: 0000-0002-4898-6476 \\ **Öğretmen, Giresun Üniversitesi, Eğitim Fakültesi, Giresun/Türkiye \\ E-Posta: tgcelvnt2928@gmail.com \\ ORCID: 0000-0002-6776-3243
}

Öz

Bu çalışmanın amacı 2015-2016 bahar yarıyllında ilk kez uygulanan Aday Öğretmen Yetiştirme Sürecinin farklı değişkenler açısından incelenmesine yönelik geçerli ve güvenilir bir ölçek geliştirmektir. Bu bağlamda araştırma 2015-2016 bahar yarılllında atanan öğretmenlerle yürütülmüştür. Araştırmanın çalışma grubunu Giresun ilinden farklı/aynı yere atanan, farklı branşlarda 110 aday öğretmen oluşturmaktadır. Geliştirilen ölçeğin geçerlik ve güvenirliğini belirlemek için açımlayıcı faktör analizi yapılmıştır. Açımlayıcı faktör analizi sonucunda, ölçeğin 16 madde ve tek faktörden oluşan bir yapıya sahip olduğu belirlenmiştir. Hazırlanan ölçeğin Cronbach Alfa iç tutarlılık katsayısı 0,81 olarak hesaplanmıştır. Faktör analizi sonucu uyum iyiliği indekslerinin, kabul edilebilir ve iyi uyum sinırlar içerisinde oldukları görülmüştür. Yapılan geçerlik ve güvenirlik analizleri sonucunda "Aday Öğretmen Yetiştirme Sürecini Değerlendirme Ölçeği" nin geçerli ve güvenilir bir ölçek olduğu bulunmuştur.

Anahtar Kelimeler: Aday öğretmen, öğretmen yetiştirme süreci, ölçek geliştirme 


\title{
A Scale Development Study on Evaluation of the Training Process of Novice Teachers
}

DOI: $10.26466 /$ opus.361334

\begin{abstract}
The aim of this study is to develop a valid and reliable scale for investigating, based on different variables, the process of training Novice teachers that was first applied in Spring Term in the Education Year of 2015 and 2016. In this context, the sample of the study is made up of a group of teachers appointed in spring term in the education year of 2015 and 2016. Hundred and ten prospective teachers of different branches, who were appointed in the same/different places in theProvince of Giresun, make up of the study-group. Explanatory factor analysis was made for the verification of the validity and reliability of the scale developed. The results obtained from the explanatory factor analysis indicated that the scale developed was based on a structure of sixteen items and only a single factor. The Cronbach Alpha internal consistency coefficient of the prepared scale was calculated as 0,81 . Based on the results of factor analysis, the index of conformity was found to be acceptable and in good conformity. The results obtained from the reliability and conformity analysis conducted indicated that 'The Scale For The Evaluation of The Process of Training Novice Teachers' was found to be reliable and valid.
\end{abstract}

Key Words: Novice teacher, teacher training process, scale development 


\section{Giriş}

Bilim ve teknoloji alanındaki hızlı değişim ve gelişmelere paralel olarak, toplumsal yapı da kendini yenilemektedir. Bu yenileşme sürecinde, değişimden etkilenen bireylerin hem gelişim sürecine uyum sağlamaları, hem de gelişim sürecine katkıda bulunabilmeleri "davranış geliştirme mühendisi" olarak tanımlanan öğretmenlere yeni sorumluluklar yüklemektedir. Belirtilen durumun doğal sonucu olarak, öğretmenlerin de nitelik ve standartlarının yeniden gözden geçirilip geliştirilmesi zorunluluğu ön plana çıkmaktadır (Aydın, Şahin ve Topal, 2008).

Bir toplumun oluşturulmasında önemli bir yere sahip olan eğitim sistemi içerisinde temel öğe öğretmenlerdir. Toplumda olması gereken değerlerin yerine getirilmesinde en önemli unsur öğretmenlerdir (Azar, 2011). Öğretmenlerin etkileme gücü diğer unsurlara göre daha etkilidir (Çapa ve Çil, 2000). Öğretmenler geleceğin mühendisini, doktorunu, avukatını, öğretmenini, askerini, polisini, şoförünü, kısacası toplumun her kesimini yetiştiren geleceğin mimarlarıdır (Özden, 1999; Çelikten, Şanal ve Yeni, 2005). Öğretmenliğin tanımı, Milli Eğitim Temel Kanunu'nda bireylerin belli bir amaç doğrultusunda belli bir hedefe başlatılması, yönlendirilmesi ve o hedefe ulaşmanın kolaylaştırılmasıyla istenilen hedefin gerçekleştirilmesi sürecine ilişkin etkinlikleri kapsayan mesleğin adıdır (Üstüner, 2006). Öğretmenlik mesleğine ilişkin sorunlar irdelendiğinde, öğretmenlerin kendilerinden beklenen rolleri yerine getirmeleri, öğretmenliği sevme, benimseme ve öğretmenliğe saygı duyma özellikleri de irdelenmektedir. Öğretmenlerin atanması, motivasyonlarındaki düşüklük, çağın gereklerine uygun bilgi ve becerilerle ilgili sorunlar yaşamaları, üniversite sınavlarında öğretmenliğin tercihlerde ilk sırada bulunmaması ve birçok sorun öğretmenlik mesleğinin tartışılan olgularıdır (Pehlivan, 2008). Bu bağlamda öğretmenlerin sorunlarını en aza indirmek için öğretmen yetiştirme sürecinin değerlendirilmesi gerekmektedir.

Dünyanın küreselleşmesiyle birlikte oluşan rekabet ortamı, daha üstün niteliklere sahip bireyler yetiştirme gereksinimi doğurmuştur. Daha üstün niteliklere sahip bireyler yetiştirmede eğitim ve eğitim sistemi önemli rol oynamaktadır. Geliştiren eğitim programlarını uygulayan, genel ve özel çerçeve içerisinde yer alan eğitimsel her türlü araca ulaşım sağlayan ve 
eğitim öğretim faaliyetlerinin en kritik rollerini üstlenen öğretmenler olmuştur. Eğitim sisteminin uygulayıcıları olan öğretmenler aynı zamanda eğitim sisteminin de belirleyicileri olarak kabul edilmektedirler. Öğretmen yetiştirme politikalarının belirlenmesinde, öğretmen yetiştiren yükseköğretim kurumlarının hizmet öncesi öğretmen yetiştirme programlarında, öğretmenlerin hizmet içi eğitiminde, öğretmenlerin seçiminde, öğretmenlerin iş başarılarının değerlendirilmesinde ve öğretmenlerin kendilerini tanıma ve kariyer gelişimlerinde kullanılması düşünülmektedir. Türkiye'de uygulanan öğretmen yetiştirme programları da sırasıyla yetiştirilecek adayların seçimi, bir süre program dâhilinde eğitimleri (hizmet öncesi eğitim), görevlendirilecek öğretmenlerin eğitimleri (hizmet içi eğitim) aşamalarından oluşmaktadır.

Uluslar, ancak sağlıklı bir eğitim sistemi aracilığıyla kalkınmanın gereksinimi olan insan gücünü yetiştirebilmektedirler. Zira iyi bir eğitim sisteminden geçmiş insanlarca ülke kaynakları, daha etkili ve daha planlı bir şekilde değerlendirilebilmektedir (Aydın, Şahin ve Topal, 2008).

1996 yılına kadar öğretmen yetiştirme uygulamalarımızda toplumun gereksinimlerine ve beklentilerine uygun bir yetiştirme süreci vardı (Üstüner, 2004). İlköğretim ve ortaöğretim kurumlarına öğretmen yetiştirmek üzere cumhuriyet sonrası dönemde birçok kurum açılmıştır (Başkan, Aydın ve Tuğba, 2006). Günümüzde ise öğretmenlik, doğrudan insanla ilgili bir meslek olması yönüyle özel uzmanlık bilgisi ve becerisi gerektiren bir meslek dalı haline gelmiştir (Şişman, 2011, 191). Öğretmenlerin sahip olması istenilen yeterliklerinin neler olması gerektiği, bu yeterliklerini ne ölçüde edinmeleri gerektiği, öğretmenlik mesleği genel yeterliklerinin nasıl öğrenileceği ve geliştirileceği hususunda bilgi düzeylerini ölçmek için yapılan sınavlar incelendiğinde, öğretmenlerin konu hâkimiyetleri, pedagojik bilgi ve beceri yetersizlikleri ortaya çıkmaktadır (Çiltaş, Işık ve Baş, 2010).Ancak,öğrencilere istedikleri öğrenme çevresinin öğretmen tarafından sağlanması, öğrencilerin sınıf (okul) ortamına bağlılığını artırarak, olumlu tutum ve davranış geliştirmelerinin de yolunu açacaktır. Öğretmenin oluşturacağı böyle bir ortam (demokratik) öğretme-öğrenme sürecinin kalitesi ve akademik başarının yükselmesinin önündeki engelleri de büyük ölçüde kaldıracaktır (Topal, 2007). Öğretmen yetiştirme süreci hizmet öncesi seçme, yetiştirme, görev başında ve hizmet içi 
yetiştirme olmak üzere dört farklı aşamada gerçekleşmektedir. Bu aşamalar birbiri ile ilişkili ve yetiştirme sürecinin tamamını oluşturan temel unsurlarıdır. Bu aşamalar öğretmen yetiştirmede büyük bir öneme sahiptir. Bu aşamaların bir basamağı olan yetiştirme basamağ "adaylık dönemi" olarak nitelendirilir. Yetiştirme basamağı, öğretmen adayını mesleğe hazırlamada pratik değeri olan ve uygulama ile en yoğun şekilde buluştuğu bir süreci kapsamaktadır. Bu anlamda öğretmenlerin mesleği benimsemelerinde ve sosyalleşmelerinde adaylık dönemi önemli bir aşamadır (Ekinci, 2010).

Hizmet öncesi öğretmen eğitim programlarından mezun olan öğretmenler esas atama yerlerinde göreve başladıklarında gerçek problemlerle karşı karşıya gelirler ve bu problemleri çözerken tecrübesizlik yaşarlar (Korkmaz ve Akbaşlı, 2004). Öğretmenlik mesleğinin ilk yılı öğretmenlerin adaptasyon sorunu yaşadıkları dönemdir. Mesleğe yeni başlayan öğretmenlerin atandıkları okullarda yaşadığı problemlerden bazıları; deneyimsizlik, hizmet öncesi eğitimde kazanılanlarla uygulamada karşılaşılan durumlar arasındaki çatışma, aday öğretmen üzerindeki sorumluluktan kaynaklı baskılar, çok şey yapma gayreti, teftiş endişesi, okula ve çevreye uyum problemleridir. (Yalçınkaya, 2002).

Son yıllarda gündem içerisinde yer alan eğitim sistemi ve bu sistemle ilgili yapılan uygulamalar; genel anlamda sorunların önemli bir boyutunu, öğretmen yetiştirme ve yetiştirilen öğretmenlerin niteliği oluşturmaktadır. Geliştirilen eğitim sistemlerinin öğretmenlik uygulamalarının birçok yönleriyle iyileştirmesi, bu mesleğe ilişkin olarak toplumun çeşitli kesimlerinin tutumlarının bilimsel bir biçimde saptanması açısından önemlidir (Erkuş, Sanlı, Bağlı ve Güven, 2000). Bu bağlamda rolleri, sorumlulukları ve kendisinden beklenenlerin farkında olan öğretmenler, mesleğin her alanına olumlu katkılarda bulunabileceklerdir. Ancak öğretmenler sorumluluklarının farkında olabilir ama sorumlulukların yerine getirilmesinde yeterli bireysel ve akademik donanıma sahip olmayabilir. Bu durum öğretmen adaylarına meslekî anlamda katkıda bulunabilmelerini olumsuz olarak etkileyebilir (Kiraz, 2003). Literatür incelendiğinde eğitim-öğretim faaliyetleri ile ilgili ölçek geliştirme çalışmaları yer almaktadır. Bu çalışmalardan bazıları; bilgisayar öğretmenleri ve bilgisayar destekli eğitim ile ilgili (Akkoyunlu, Orhan ve Umay, 2005; Arslan, 2006; Dal ve Aktay, 2015); öğretmenlik mesleğiyle ilgili (Erkuş, Sanlı, Bağlı ve 
Güven, 2000; Üstüner, 2006); çokkültürlü yeterlik algısıyla ilgili (Başbay ve Kağnıc1, 2011); eğitme-öğretme özyetkinliği ve öğrenme kaygısı ile ilgili (Kan, 2007; Doğan, 2010; Yıldırım, 2015) dır.

Özetle aday öğretmenlerin yetiştirme sürecini farklı değişkenler (mezun olunan bölüm, cinsiyet, KPSS atama puanı) açısından değerlendiren çalışmaların kısıtlı olduğu literatür içerisinde görülmektedir. Milli Eğitim Bakanlığı tarafından geliştirilen aday öğretmen yetiştirme sürecinin, mesleğe yeni başlayan aday öğretmenlerin demografik özellikleriyle hizmetin niteliğine ilişkin görüşleri arasında bir ilişkinin olup olmadığı akla gelmektedir. Bu bağlamda aday öğretmenlerin yetiştirilme sürecinin hazırlanan bir ölçekle irdelenmesi; motivasyonlarını ve başarılarını arttırmaları, öğretmenlerin sınıf yönetimiyle ilgili sorunları çözebilmeleri, etkili planlama, uygulama ve değerlendirme faaliyetleri gerçekleştirmeleri açısından olumlu yönde etki sağlayacağının inancı bu çalışmanın yapılmasının gerekliliğini ön plana çıkarmaktadır. Bu bağlamda çalışma "Aday Öğretmen Yetiştirme Sürecini Değerlendirmeye Yönelik Ölçek Geliştirme Çalışması" adını taşımaktadır.

\section{Yöntem}

Bu araştırmanın çalışma grubunu; 2016 Şubat dönemi ataması ile kadrolu pozisyonlara yerleştirilen ve Giresun ilinde adaylık eğitimini tamamlayan farklı branşlarda görevli 110 aday öğretmen oluşturmaktadır. Aday öğretmenlerin görev yaptıkları branşlar aşağıdaki tabloda belirtilmiştir.

Tablo 1. Çalışma Grubunun Branş Dă̆ılımları

\begin{tabular}{lll}
\hline Bölüm Adı & Sayı (n) & Yüzde (\%) \\
\hline Sinıf Öğretmenliği & 25 & 22.7 \\
\hline Din Kültürü ve Ahlak Bilgisi Öğretmenliği & 18 & 16.3 \\
\hline İngilizce Öğretmenliği & 13 & 11.8 \\
\hline Okul Öncesi Öğretmenliği & 9 & 8.1 \\
\hline Mesleki Teknik Öğretmenleri & 9 & 8.1 \\
\hline Türkçe Öğretmenliği & 8 & 7.2 \\
\hline Rehberlik ve Psikolojik Danışmanlık & 6 & 5.4 \\
\hline Matematik Öğretmenliği & 5 & 4,5 \\
\hline Müzik Öğretmenliği & 4 & 3.6 \\
\hline Sosyal Bilgiler Öğretmenliği & 3 & 2.7
\end{tabular}




\begin{tabular}{lll}
\hline \hline Özel Ĕ̆itim Öğretmenliği & 3 & 2.7 \\
\hline Bilişim Öğretmenliği & 3 & 2.7 \\
\hline Beden Eğitimi & 1 & 0.9 \\
\hline Fen Bilgisi Öğretmenliği & 1 & 0.9 \\
\hline Fizik Öğretmenliği & 1 & 0.9 \\
\hline Biyoloji Öğretmenliği & 1 & 0.9 \\
\hline Toplam & $\mathbf{1 1 0}$ & $\mathbf{1 0 0}$ \\
\hline
\end{tabular}

Tablo 1'de görüldüğü gibi, çalışma grubunun \%22,7'sini Sınıf Öğretmenliği, \%16,3'ünü Din Kültürü ve Ahlak Bilgisi Öğretmenliği, \%11,8'ini İngilizce Öğretmenliği, \%8,1'ini Okulöncesi ve Mesleki Teknik öğretmenleri, \%7,2'sini Türkçe öğretmenliği oluştururken \%5,4'ünü ise Rehberlik ve Psikolojik Danışmanlık oluşturmaktadır. Benzer şekilde grubun \%4,5'ini Matematik Öğretmenliği oluştururken \%3,6'sını Müzik Öğretmenleri oluşturmaktadır. Yine çalışma grubunun \%2,7'sini ise Sosyal Bilgiler Öğretmenliği, Özel Eğitim Öğretmenliği ve Bilişim Öğretmenlerinin oluşturduğu görülmektedir. Son olarak çalışma grubunun \%0,9'unu Fen Bilgisi Öğretmenliği, Beden Eğitimi Öğretmenliği, Fizik ve Biyoloji Öğretmenliği oluşturmaktadır.

Tablo 2. Çalışma Grubunun Özellikleri

\begin{tabular}{lll}
\hline Aday Öğretmenlerin Özellikleri & $\begin{array}{l}\text { Sayı } \\
(\mathrm{n})\end{array}$ & $\begin{array}{l}\text { Yüzde } \\
(\%)\end{array}$ \\
\hline Cinsiyet & & \\
\hline Kız & 74 & 67.2 \\
\hline Erkek & 36 & 32.7 \\
\hline
\end{tabular}

KPSS Atama Puanı

\begin{tabular}{lll}
\hline $0-70$ Puan Aralı̆̆ 1 & 24 & 21.8 \\
\hline $70-80$ Puan Aralığ 1 & 55 & 50 \\
\hline 80 ve üzeri & 17 & 15.4 \\
\hline Belirtilmemiş & 14 & 12.7 \\
\hline Mezuniyet Yılı & & \\
\hline 2010 ve üzeri & 94 & 85,4 \\
\hline $2001-2010$ Aralığı & 7 & 6.3 \\
\hline 1990-2000 Aralı̆̆ 1 & 2 & 1.8 \\
\hline Toplam & $\mathbf{1 1 0}$ & $\mathbf{1 0 0}$ \\
\hline
\end{tabular}


Tablo 2'de görüldüğg̈u gibi, çalışma grubunda yer alan Aday öğretmenlerin \%67,2'si kadınlardan, \%32,7'sini ise erkeklerden oluşmaktadır. Çalışma grubunun KPSS atama puanları incelendiğinde, 0-70 arası puan aralığ1 grubun \%21'ini, $70-80$ puan aralığ 1 ise grubun \%50'sini oluştururken, 80 ve üzeri ise grubun \%15,4'ünü oluşturmaktadır. Çalışma grubunun \%12,7'si ise puan aralığı belirtmemiştir. Benzer şekilde çalışma grubunun mezuniyet yılı incelendiğinde 2010 ve üzerinde mezun olan aday öğretmenler grubun \%85,4'ünü oluştururken, 2001 ve 2010 yılları arasında mezun olan aday öğretmenler çalışma grubunun \%6,3'ünü oluşturmaktadır. 1990-2000 yılları arasında mezun olan aday öğretmenler grubun $\% 2$ 'sini oluştururken, grubun $\% 6,3$ 'ü mezuniyet yılını belirtmemiştir.

\section{Ölçeğin Geliştirme Süreci}

Ölçeğin geliştirilmesi sürecinde, öncelikle aday öğretmenlik yetiştirme sürecine ilişkin alan yazın taraması gerçekleştirilmiştir. Alan yazından elde edilen bilgiler ışığında aday öğretmen yetiştirme sürecinin tarihsel süreci, Milli Ĕ̆itim Bakanlığı' nın öğretmen yetiştirme programları ve aday öğretmen yetiştirme sürecinin kapsamı hakkında genel çerçeve oluşturulmuştur.

Alan yazından elde edilen bilgiler ve alan uzmanlarının görüşleri doğrultusunda 39 maddelik ölçek maddesi oluşturulmuştur. Oluşturulan ölçek içerisinde ölçülmek istenilen tutum ve davranışları sergileme sıklıklarını belirlemek amacıyla beşli Likert tipi olarak derecelendirilmiştir. Bu seçenekler sırasıyla Kesinlikle Katılmıyorum (1), Katılmıyorum (2), Kararsızım (3), Katılıyorum (4) ve Kesinlikle Katılıyorum (5) biçiminde düzenlenmiştir.

Taslak biçiminde oluşturulmuş olan maddeler ilgili uzmanlar tarafından detaylı bir biçimde incelenmiş ve ölçek bağlamında uzman görüşü alınmıştır. Ölçek hazırlanırken ilgili alandaki uzmanlar ölçme ve değerlendirme, Matematik Eğitimi, Program Geliştirme, vb. birçok boyutta görüş bildirmiştir.

Yapılan eleştiriler ve öneriler değerlendirildikten sonra geri dönütler ışığında ölçek içerisinde gerekli düzeltmeler yapılarak Giresun iline 
atanmış olan grup içerisinden 20 aday öğretmene ön deneme amacıyla uygulanarak öğretmenler tarafından anlamlandırılamayan maddeler düzeltilme yoluna gidilmiştir. Son hali verilen taslak ölçek 110 aday öğretmene tekrar uygulanmıştır. Elde edilen veriler istatistiksel olarak ölçeğin geçerlik ve güvenirlik analizlerini yapmak üzere SPSS 20.00 paket programına girilmiş ve istatistiksel işlemlere tabi tutulmuştur.

\section{Bulgular}

\section{Yapı Geçerliliği}

Ölçeğin yapı geçerliliğini test etmek üzere veriler üzerinde ilk olarak Kaiser-Meyer-Olkin (KMO) ve Bartlett test analizleri yapılmış ve $\mathrm{KMO}=.840$; Bartlett testi değeri ise $\mathrm{x}^{2}=377,688 ; \mathrm{sd}=120(\mathrm{p}=.000)$ olarak belirlenmiştir. $\mathrm{KMO}$ değerinin 0.60 veya üstünde bir değer olması ve Bartlett testinin $\mathrm{p}$ değerinin ise ,05 ve altında olması önerilmektedir (Pallant, 2013). Bu değerler göz önüne alınarak 39 maddelik taslak ölçek üzerinde faktör analizi yapılabileceği gözlenmiştir. Faktör analizi, aynı yapıyı ya da niteliği ölçen değişkenleri bir araya toplayarak ölçmeyi az sayıda faktör ile açıklamayı amaçlayan bir istatistiksel tekniktir (Büyüköztürk, 2012, 123).

Ölçeğin maddelerini temsil eden faktör sayısının belirleme yoluna gidilmiştir. Faktör analizinde ölçeği en iyi temsil eden faktörleri ve gerekli faktör sayısını ortaya koymak için az ölçüde faktör elde edilmesi ve ölçeğin fazla miktarda varyansı açıklaması önem arz etmektedir. Kuramsal yapının temsil edilebilmesinin yanı sıra, faktör analizinde faktör sayısını belirleyen en önemli teknikler, en çok kullanılan yaklaşım olan temel bileşenler analizi ve bu analize destek olarak Kaiser ölçütü, Scree Plot grafiği yer almaktadır. (Pallant, 2013). Bu çerçevede ilk aşamada, ölçeğin boyutlarını belirlemek için ilk olarak varyans değerlerine, Scree Plot grafiğine ve faktör analizi tablosundaki değerlere bakılmıştır. Açılanan varyans oranları incelendiğinde tekli faktör analizinin varyansı açıklayabildiği ve bu faktörün varyansı açıklama oranının yüksek olduğu görülmüştür. Scree Plot grafiğine bakıldığında ise birinci faktörden sonra yüksek ivmeli bir düşüş olduğu gözlenmiş ve faktör analizindeki değerlerin çoğunun birinci faktörde yüksek değerlerle toplandığı görülmüştür. Dolayısıyla ölçeğin tek faktörlü bir yapıda olduğu gözlenmiştir. 
Ölçeğe ilişkin yapılan faktör analizinde, faktör yük değerleri için kabul düzeyi 0,33 olarak belirlenmiştir. Analiz sürecinde, maddelerin faktör yükü değerin altında olan maddeler dışarıda bırakılarak analiz tekrarlanmıştır. Dışarıda bırakılan maddeler (m1, m5, m7, m11, m12, m13, m14, $\mathrm{m} 16, \mathrm{~m} 17, \mathrm{~m} 18, \mathrm{~m} 19, \mathrm{~m} 20, \mathrm{~m} 23, \mathrm{~m} 24, \mathrm{~m} 25, \mathrm{~m} 27, \mathrm{~m} 28, \mathrm{~m} 30, \mathrm{~m} 31, \mathrm{~m} 34, \mathrm{~m} 35$, m37, m38) sonrasında geriye kalan 16 madde üzerinden ölçeğin KMO değeri belirlenmiştir. Elde edilen veriler aşağıda Tablo 3.1.1'de verilmiştir.

\begin{tabular}{|c|c|c|}
\hline \multicolumn{3}{|c|}{ Tablo 3.1.1. KMO and Bartlett's Test } \\
\hline \multicolumn{2}{|c|}{ Kaiser-Meyer-Olkin Measure of Sampling Adequacy. } & 840 \\
\hline \multirow[t]{3}{*}{ Bartlett's Test of Sphericity } & Approx. Chi-Square & 377,688 \\
\hline & $\mathrm{df}$ & 120 \\
\hline & Sig. &, 000 \\
\hline
\end{tabular}

Tablo 3.1.1. incelendiğinde ölçeğin, KMO: .840; Bartlett testi değeri incelendiğinde ise $x^{2}: 377,688$ sd: 120 , p: .000 olarak belirlenmiştir. Ölçekte yer alan 29 maddenin faktör yüklerinin .340 ve .673 arasında olduğu görülmektedir. Ölçeğe ait scree plot grafiği Şekil 3.1.1.'de görülmektedir.

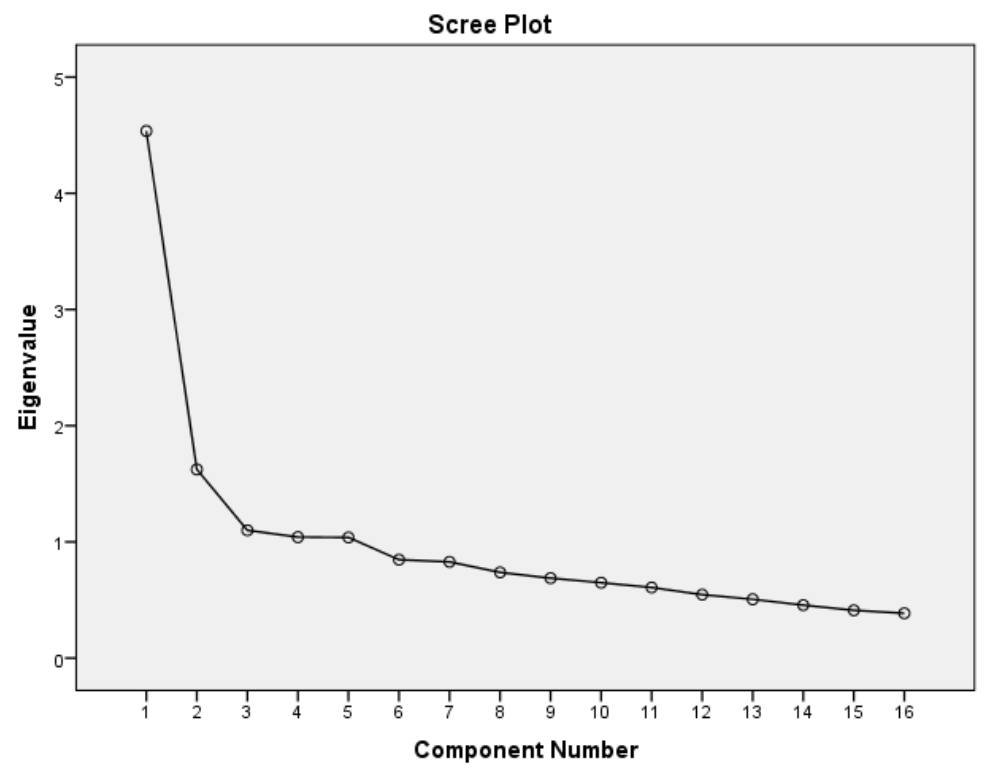

Şekil 3.1.1. Faktörlere ilişkin Scree Plot grafiği 
Şekil 1'de de görüldüğü gibi, ilk faktörden sonra ivmeli bir düşüş olduğu, daha sonra bu ivmenin yavaşlayarak düşüşe devam ettiği ve yatay eksene yaklaştığ 1 görülmektedir. Dolayısıyla ilk faktörden sonra gelenlerin varyansa sağladığı katkı birbirine yaklaşmaktadır. Ölçek içerisinde geçerli 16 maddenin faktör yük değerlerine ilişkin bulgular Tablo 3.1.2'de yer almaktadır.

\section{Tablo 3.1.2. Faktördeki maddelerin faktör yük değerleri}

\begin{tabular}{|c|c|c|}
\hline No & Madde & $\begin{array}{l}\text { Yük } \\
\text { Değeri }\end{array}$ \\
\hline $\mathbf{m} 21$ & $\begin{array}{l}\text { Seçtiğim ilde bulunan danışman öğretmen benim yetiştirme sü- } \\
\text { recimi başarılı olarak tamamlamam için gerekli dönütleri verir. }\end{array}$ & 673 \\
\hline m36 & $\begin{array}{l}\text { Süreç içerisinde edindiğim tecrübeleri, öğrencilerime etkili bir } \\
\text { biçimde yansitabileceğimi düşünüyorum. }\end{array}$ & 628 \\
\hline m32 & $\begin{array}{l}\text { Adaylık eğitimimi tamamladığımda kendi sınıfımda öğrenci } \\
\text { başarısını artıracağıma inanıyorum. }\end{array}$ & 620 \\
\hline m8 & $\begin{array}{l}\text { Danışman öğretmenim bana sınıf yönetiminde yeterli fırsatlar } \\
\text { tanıdı. }\end{array}$ & 619 \\
\hline m33 & $\begin{array}{l}\text { Öğrencilerimin hangi derslerde eksik olabileceğini ve buna } \\
\text { karşı almam gereken önlemleri danışman öğretmenimden } \\
\text { öğrendim. }\end{array}$ & 618 \\
\hline $\mathbf{m} 26$ & $\begin{array}{l}\text { Üniversite eğitimi içerisinde aldığımız teorik bilgiyi uygulama } \\
\text { fırsatını süreç bana başarılı bir biçimde sağladı. }\end{array}$ & ,572 \\
\hline $\mathrm{m} 9$ & $\begin{array}{l}\text { Süreç içerisinde yeni öğretim yöntemleri öğrendiğime } \\
\text { inaniyorum. }\end{array}$ & ,544 \\
\hline m6 & $\begin{array}{l}\text { Danışman öğretmenlerimin alanında yeterli deneyime sahip } \\
\text { olduğunu düşünmüyorum. }\end{array}$ & ,519 \\
\hline $\mathbf{m} 22$ & $\begin{array}{l}\text { Aday öğretmen yetiştirme süreci içerisinde seçilen danışman } \\
\text { öğretmenlerin en az } 10 \text { yıl kıdeme sahip olması benim mesleki } \\
\text { yeterliliğimi karşılamada yeterlidir. }\end{array}$ & ,502 \\
\hline $\mathrm{m} 2$ & $\begin{array}{l}\text { Aday öğretmen yetiştirme sürecinin ileride meslek hayatıma } \\
\text { katkı sağlayacağını düşünmüyorum. }\end{array}$ & 493 \\
\hline m39 & Adaylık sürecine başladığım okulda kalmak isterdim. & 429 \\
\hline $\mathbf{m} 29$ & $\begin{array}{l}\text { Çalıştığım kurumdaki çalışma arkadaşlarım bana öğretmen } \\
\text { statüsünde değer verir. }\end{array}$ & 424 \\
\hline $\mathbf{m 1 0}$ & Aday öğretmen yetiştirme sürecinin takvimi benim için yeterli. & 392 \\
\hline $\mathbf{m 4}$ & $\begin{array}{l}\text { Gözlem formlarının adaylık eğitimine katkı sağladığına } \\
\text { inanıyorum. }\end{array}$ & 344 \\
\hline
\end{tabular}


Tablo 3.1.2'de görüldüğü gibi, maddelerin, .344 ile .673 arasında değiştiği görülmektedir. Faktörün varyansa sağladığı katkı miktarı \%34,672 dır. Tek faktörlü ölçeklerde bu durumun ölçeği yeterli derecede açıkladığ 1 görülmektedir. Nitekim tek faktörlü ölçekler için açıklanmış olan varyansın yüzdesini $\% 30$ ve üzerinde olması gerekmektedir. (Büyüköztürk 2012, s. 123).

\section{Ölçeğin Güvenirliğine ilişkin Bulgular}

İlk olarak ölçeğin madde toplam korelâsyonuna bakılarak maddelerinin ölçeğin bütününden alınan puanla korelâsyonunun yükseklik derecesi incelenmiştir. Ölçek maddesinin puan ile ölçeğin bütününden alınan puan arasındaki korelasyon ölçülmek istenen kavramı ne kadar iyi ölçtüğünün göstergesidir. Ayrıca ölçüt geçerliğii için, ölçek puanlarına dayalı olarak aşırı uçları üst grup ve alt grup olarak ayırdıktan sonra, bu iki grubun ortalamaları arasındaki farkın anlamlı olup olmadığı madde analiziyle ortaya koyulmuştur. Bu bağlamda ölçekle ilgili olarak ayrıca katılımcların ölçek ortalama puanlarına göre oluşturulmuş \%27'lik üst grup ile \%27'lik alt grubun puanları, her bir madde ve ayrıca faktör olarak bağımsız örneklemler için $t$ testine tabi tutularak grupların madde ortalama puanları arasındaki farka bakılmıştır. Madde toplam korelasyonları arasındaki korelasyon verileri ile \%27'lik alt-üst grup farkına ilişkin t değerleri Tablo 3.2.1'de görülmektedir.

Tablo 3.2.1. Ölçeğin Düzeltilmiş Madde Toplam Korelasyonlan ile \%27'lik Alt-Üst Grup Farkına İlişkin t Değerleri

\begin{tabular}{|c|c|c|}
\hline Madde & Madde Toplam Korelasyonu & t (Alt \%27-Üst \%27) \\
\hline $\mathrm{m} 2$ & .409 & 4,619 \\
\hline $\mathrm{m} 4$ & .300 & 4,434 \\
\hline m6 & .410 & 3,292 \\
\hline $\mathrm{m} 8$ & .519 & 5,418 \\
\hline m9 & .451 & 6,501 \\
\hline m10 & .320 & 4,347 \\
\hline $\mathbf{m} 21$ & .559 & 5,390 \\
\hline $\mathrm{m} 22$ & .400 & 3,985 \\
\hline $\mathbf{m} 26$ & .479 & 4,762 \\
\hline m29 & .324 & 3,557 \\
\hline
\end{tabular}




\begin{tabular}{lll}
\hline $\mathbf{m} 32$ & .517 & 5,046 \\
\hline $\mathbf{m} 33$ & .500 & 6,578 \\
\hline $\mathbf{m 3 6}$ & .505 & 5,711 \\
\hline $\mathbf{m 3 9}$ & .328 & 3,791 \\
\hline
\end{tabular}

Tablo 3.2.1'de görüldüğü üzere ölçek maddelerinin toplam madde korelasyonu .300 ile .559 arasındadır. Bu bağlamda değerlendirildiğinde ölçek maddelerinin tümünün düzeltme gerektirmeyecek sınırda kabul edilen .30 'un üzerinde olduğu görülmektedir. \%27'lik alt grubun puanlarına ilişkin analiz sonucunda ise tüm maddeler ve genel faktör ( $\mathrm{p}<.001)$ düzeyinde anlamlı bulunmuştur. Tek faktörden oluşan 16 maddelik ölçeğin güvenirlik analizi; Cronbach alpha güvenirlik katsayısı, iki yarı arasındaki korelasyon değeri, Sperman-Brown formülü ve Guttmann split-half güvenirlik testi kullanılarak analiz edilmiştir. Ölçeğe ilişkin güvenirlik analizi verileri Tablo 3.2.1.'de gösterilmektedir.

Tablo 3.2.2. Güvenirlik Testi Test Sonucu

\begin{tabular}{ll}
\hline \hline Cronbach Alpha & .813 \\
\hline Guttmann Split-Half & .704 \\
\hline
\end{tabular}

Tablo 3.2.2'de görüldüğü gibi ölçeğin CronbachAlpha güvenirlik değeri .813, Guttmann Split-Half değeri .704 ve Spearman Brown güvenirlik değeri .710 olarak bulunmuştur. Büyüköztürk (2012) çalışmasında güvenirlik değerenin 70 ve üzerü olması gerektiğini vurgulamıştır. Böylece ölçekte yer alan maddelerin güvenilir olduğu yorumu yapılabilir.

\section{Sonuç}

Bu çalışma aday öğretmen yetiştirme sürecini değerlendirmeye yönelik ölçek geliştirme çalışmasıdır. Sürece ilişkin görüşlerin belirlenmesine ilişkin hazırlanan ölçeğe beş dereceli likert tipi seçenekler yerleştirilmiştirElde edilen veriler üzerinden yapılan açımlayıcı faktör analizi sonucunda, ölçeğin 16 maddeden oluşan tek faktörlü bir yapıya sahip olduğu, maddelerin faktör yüklerinin .344 ile .673 arasında değiştiği ve 
varyansın \%34'ünü açıkladığı belirlenmiştir. Bununla birlikte, ölçek maddelerinin madde toplam korelasyonu .300 ile .544 arasında değiştiği sonucuna ulaşılmıştır. Ölçek maddelerinin tümünün düzeltme gerektirmeyecek sınır kabul edilen .300'un üzerinde olduğu görülmüştür. Bununla birlikte ölçekle ilgili olarak katılımcıların ölçek ortalama puanlarına göre oluşturulmuş \%27'lik üst grup ile \%27'lik alt grubun puanları, her bir madde ve faktör olarak bağımsız örneklemler için $t$ testine tabi tutularak grupların madde ortalama puanları arasındaki fark sınanmış ve analiz sonucunda tüm maddedeler ve genel faktör $(\mathrm{p}<.001)$ düzeyinde anlamlı bulunmuştur. Ölçeğin güvenirlik testlerinde, Cronbach Alpha güvenirlik değeri .813, Guttmann Split-Half değeri .704, Spearman Brown güvenirlik değeri .710 bulunmuştur. Bu değerler ölçeğin güvenilir olduğunu göstermektedir. $\mathrm{Bu}$ bağlamda hazırlanan ölçekle aday öğretmen yetiştirme sürecine ilişkin güvenilir ölçümler elde edilebileceği sonucuna ulaşılmıştır. Aday öğretmenlerin ilgili sürece yönelik düşünceleri doğrultusunda düzenlemelerin yapilabileceğ ve araştırmacılara değişen ve gelişen öğretmen yetiştirme sürecini değerlendirmeleri noktasında klavuz olan bu çalışmayla sürece ilişkin başka boyutların ele alanınmasının gerekliliği önerilebilir.

\section{KAYNAKÇA}

Akkoyunlu, B., Orhan, F., ve Umay, A. (2005). Bilgisayar öğretmenleri için" bilgisayar öğretmenliği öz yeterlik ölçeği" geliştirme çalışması. Hacettepe Üniversitesi Ĕ̆itim Fakültesi Dergisi, 29(29), 1-8.

Arslan, A. (2006). Bilgisayar destekli eğitim yapmaya ilişkin tutum ölçeği. Yüzüncü Yal Üniversitesi Eğitim Fakültesi Dergisi, 3(2), 24-33.

Aydın, R.; Şahin, H. ve Topal, T. (2008). Türkiye'de İlköğretime Sınıf Öğretmeni Yetiştirmede Nitelik Arayışları. Türkiye Sosyal Araştırmalar Dergisi, 12, (2), 119-142.

Azar, A. (2011). Türkiye' deki öğretmen eğitimi üzerine bir söylem: Nitelik mi, nicelik mi. Yükseköğretim ve Bilim Dergisi, 1(1), 36-38.

Başbay, A., Kağnıcı, D. Y. (2011). Çokkültürlü yeterlik algıları ölçeği: Bir ölçek geliştirme çalışması. Eğitim ve Bilim, 36(161), 199-212. 
Başkan, G. A., Aydın, A., ve Tuğba, Ö. (2006). Türkiye'deki öğretmen yetiştirme sistemine karşılaştırmalı bir bakış. Çukurova Üniversitesi Sosyal Bilimler Enstitüsü Dergisi, 15(1), 35-42.

Büyüköztürk, Ş. (2012). Sosyal Bilimler İçin Veri Analizi El Kitabı. Ankara: Pegem Akademi, 17. Baskı.

Çapa, Y., ve Çil, N. (2000). Öğretmen adaylarının öğretmenlik mesleğine yönelik tutumlarının farklı değişkenler açısından incelenmesi. Hacettepe Üniversitesi Ĕ̆itim Fakültesi Dergisi, 18(18), 69-73.

Çelikten, M., Şanal, M., ve Yeni, Y. (2005). Öğretmenlik mesleği ve özellikleri. Erciyes Üniversitesi Sosyal Bilimler Enstitüsü Dergisi, 19(2), 207-237.

Doğan, T. (2010). Sosyal Görünüş Kaygısı Ölçeği'nin (SGKÖ) Türkçe uyarlaması: geçerlik ve güvenirlik çalışması. Hacettepe Üniversitesi Ĕ̆itim Fakültesi Dergisi, 39(39), 151-159.

Dal, S., ve Aktay, S. (2015). İnternet İçin Eleştirel Okuryazarlik Ölçeği Geliştirme Çalişmasi. Journal of Academic Studies, 17(67), 185-200.

Ekinci, A. (2010). Aday öğretmenlerin iş başinda yetiştirilmesinde okul müdürlerinin rolü. Dicle University Journal of Ziya Gokalp Education Faculty, 15, 63-77.

Erkuş, A., Sanlı, N., Bağlı, M. T., ve Güven, K. (2000). Öğretmenliğe ilişkin tutum ölçeği geliştirilmesi. Ĕ̆gitim ve Bilim, 25(116), 27-33.

Işık, A., Çiltaş, A., ve Baş, F. (2010). Öğretmen yetiştirme ve öğretmenlik mesleği. Atatürk Üniversitesi Sosyal Bilimler Enstitüsü Dergisi, 14(1), 53-62.

Kan, A. (2007). Öğretmen adaylarının eğitme-öğretme özyetkinliğine yönelik ölçek geliştirme ve eğitme-öğretme özyetkinlikleri açısından değerlendirilmesi (Mersin üniversitesi örneği). Mersin Üniversitesi Eğitim Fakültesi Dergisi, 3(1), 1-20.

Korkmaz, İ., ve Akbaşlı, S. (2004). Göreve yeni başlayan sınıf öğretmenlerinin karşılaştıkları güçlükler. Kuram ve Uygulamada Ĕ̆itim Yönetimi, 38(38), 266-277.

Kiraz, E. (2003). Uygulama öğretmeni yeterlilik ölçeği: Ölçü aracı geliştirme örneği. Türk Ĕ̆itim Bilimleri Dergisi, 1(4), 387-398.

Özden, Y. (1999). Eğitimde Dönüşüm Eğitimde Yeni Değerler, Ankara: Pegem A Yayinlar1, s.9.

Pallant, J. (2013). SPSS survival manual. McGraw-Hill Education (UK). 
Pehlivan, K. B. (2008). Sınıf öğretmeni adaylarının sosyo-kültürel özellikleri ve öğretmenlik mesleğine yönelik tutumları üzerine bir çalışma. Mersin Üniversitesi Eğitim Fakültesi Dergisi, 4(2), 151-168.

Şişman, M. (2011). Eğitim bilimine giriş. PegemA Yayıncılık.

Topal, T. (2007). İlköğretim Sınıf Öğretmenlerinin Sınıf Yönetimi Davranışlarının Karşılaştırılması ve Öğrenci Başarısı ile İlişkisi. Yayımlanmamış doktota tezi, Ankara Üniversitesi Eğitim Bilimleri Enstitüsü, Ankara.

Üstüner, M. (2006). Öğretmenlik mesleğine yönelik tutum ölçeğinin geçerlik ve güvenirlik çalışması. Kuram ve Uygulamada Eğitim Yönetimi, 45(45), 109-127.

Üstüner, M. (2004, Haziran). Geçmişten Günümüze Türk Eğitim Sisteminde Öğretmen Yetiştirme ve Günümüz Sorunları. Bildiri Özeti olarak Sunuldu. Ankara.

Yalçınkaya, M. (2002). Yeni öğretmen ve teftiş. Milli Eğitim Dergisi, 150(153-154), 153-154.

Yıldırım, B. (2015). Fen Bilimleri Öğrenme Kaygı Ölçeği: Geçerlilik Ve Güvenirlik Çalışması. Muş Alparslan Üniversitesi Sosyal Bilimler Dergisi, 3(1), 33-43.

\section{Kaynakça Bilgisi / Citation Information}

Aksu, H. H., ve Durmuş, T. (2017). Aday öğretmen yetiştirme sürecini değerlendirmeye yönelik ölçek geliştirme çalışması OPUS Uluslararası Toplum Araştırmaları Dergisi, 7(13), 616-631. 